This is an electronic reprint of the original article. This reprint may differ from the original in pagination and typographic detail.

Author(s): Shaikh, Aijaz A.; Karjaluoto, Heikki

Title: Mobile banking adoption: A literature review

Year: $\quad 2015$

Version:

Please cite the original version:

Shaikh, A. A., \& Karjaluoto, H. (2015). Mobile banking adoption: A literature review.

Telematics and Informatics, 32(1). https://doi.org/10.1016/j.tele.2014.05.003

All material supplied via JYX is protected by copyright and other intellectual property rights, and duplication or sale of all or part of any of the repository collections is not permitted, except that material may be duplicated by you for your research use or educational purposes in electronic or print form. You must obtain permission for any other use. Electronic or print copies may not be offered, whether for sale or otherwise to anyone who is not an authorised user. 


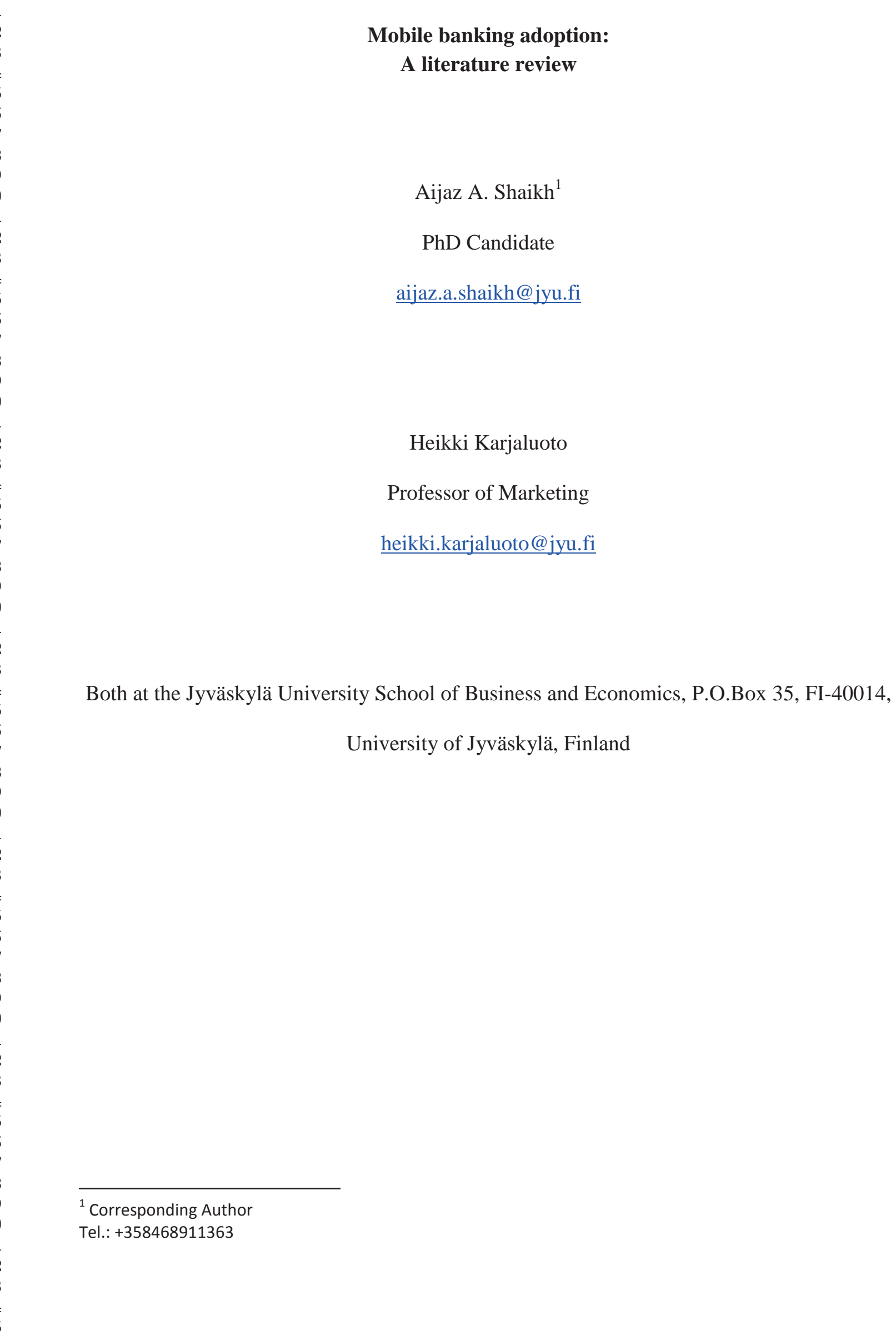




\title{
Mobile banking adoption: A literature review
}

\author{
Abstract \\ Electronic commerce (e-commerce) continues to have a profound impact on the global \\ business environment, but technologies and applications also have begun to focus more on \\ mobile computing, the wireless Web, and mobile commerce. Against this backdrop, mobile \\ banking (m-banking) has emerged as an important distribution channel, with considerable \\ research devoted to its adoption. However, this research stream has lacked a clear roadmap or \\ agenda. Therefore, the present article analyzes and synthesizes existing studies of m-banking \\ adoption and maps the major theories that researchers have used to predict consumer \\ intentions to adopt it. The findings indicate that the m-banking adoption literature is \\ fragmented, though it commonly relies on the technology acceptance model and its \\ modifications, revealing that compatibility (with lifestyle and device), perceived usefulness, \\ and attitude are the most significant drivers of intentions to adopt m-banking services in \\ developed and developing countries. Moreover, the extant literature appears limited by its \\ narrow focus on SMS banking in developing countries; virtually no studies address the use of \\ m-banking applications via smartphones or tablets or consider the consequences of such \\ usage. This study makes several recommendations for continued research in the area of \\ mobile banking.
}

Keywords: literature review, mobile banking, m-banking, mobile banking adoption, technology acceptance model 


\section{Introduction}

Mobile banking (m-banking) is among the latest in a series of recent mobile technological wonders. Although automated teller machine (ATM), telephone, and Internet banking offer effective delivery channels for traditional banking products, but as the newest delivery channel established by retail and microfinance banks in many developed and developing countries, m-banking is likely to have significant effects on the market (Safeena et al., 2012). In particular, the expanded uses of smartphones has increased demand for mbanking services, prompting many more banks, microfinance institutions, software houses, and service providers to offer this innovative service together with new sets of products and applications designed to extend their client reach (including to unbanked populations), improve customer retention, enhance operational efficiency, increase market share, and provide new employment opportunities (Shaikh, 2013).

Despite such benefits, the use of mobile phones or tablets to conduct banking transactions or access financial information is not as widespread as might be expected (e.g., Dineshwar and Steven, 2013; Luarn and Lin, 2005; Shih et al., 2010), as demonstrated by popular media reports (e.g., Accenture, 2013). Juniper Research (2013) has revealed that more than 1 billion people are expected to use m-banking globally by 2017, but that level represents only $15 \%$ of the global mobile subscription base-a base that accounts for approximately 96\% of the world's population (International Telecommunication Union, 2011). In addition, approximately half of all mobile subscribers remain unbanked, with limited access to traditional financial services, as Table 1 reveals.

"Please insert Table 1 about here"

These trends suggest that significant growth opportunities remain, leading to predictions of potentially massive increases in the number of m-banking users. These figures also warrant 
further investigations of any persistent adoption issues in m-banking, especially in the case of mobile subscribers.

Several studies analyze m-banking and associated factors that influence consumers' adoption of it, using both qualitative and quantitative methods. Despite considerable research on m-banking adoption that has appeared in international journals across disciplines, a review of literature on m-banking adoption remains missing. Such a review represents an important milestone in the development of a research field. It provides an opportunity to step back and review the collective intelligence that has been amassed from an eclectic body of research that uses various samples, methods, and theories. This effort is particularly important when the findings of isolated studies contradict one another (Hanafizadeh et al., 2014). This study accordingly seeks to extend the understanding of mobile technologies by undertaking a detailed review of m-banking adoption.

Considering the complexity of mobile technology and the variety of services being offered, this study seeks to contribute to the m-banking literature by exploring and analyzing the current state of knowledge on m-banking and its adoption across various strata of populations living in both developed and developing countries. In so doing, it can unify and synthesize disparate streams of research into a more coherent body of knowledge, as well as identify and discuss the methodologies, frameworks, and models applied in this field. Finally, this study summarizes the major findings and identifies gaps that demand further research. For these efforts, this study relies on the term "participant" to denote the unit of analysis used in any reviewed study. Only factors or antecedents that determine m-banking adoption, preadoption, or acceptance appear in this review.

The next section contains a brief overview of m-banking and its definition. After presenting the research methodology, this article outlines the results of the analysis, some conclusions and limitations, and finally, recommendations for research. 


\section{M-Banking}

M-banking dates back to the end of the 1990s when the German company Paybox, in collaboration with Deutsche Bank, launched the first service. Initially, it was deployed and tested mostly in European countries: Germany, Spain, Sweden, Austria, and the United Kingdom. Among developing countries, Kenya was the first to introduce a text-based mbanking service, M-Pesa, in 2007. By 2012, there were more than seven million registered MPesa users in Kenya. As Veijalainen et al. (2006) argue, the main driving force for the rapid acceptance of small mobile devices is the capability they offer for obtaining services and running applications at any time and any place, including while on the move.

Researchers use various terms to refer to mobile banking, including m-banking (Liu et al. 2009), branchless banking (Ivatury and Mas, 2008), m-payments, m-transfers, m-finance (Donner and Tellez 2008), or pocket banking (Amin et al., 2006). As an important component of electronic banking, m-banking usually constitutes an alternative delivery channel (ADC) for various financial and non-financial transactions, as summarized in Table 2. Other prominent ADCs include ATMs, point-of-sale terminals, interactive voice response, mobile phones, and the Internet.

\section{"Please insert Table 2 about here"}

Regardless of the terminology they use, scholars generally define m-banking as an application of m-commerce that enables customers to access bank accounts through mobile devices to conduct transactions such as checking account status, transferring money, making payments, or selling stocks (e.g., Alafeef at el., 2012; Harma and Dubey, 2009; Lee and Chung, 2009). In addition, a few studies (e.g., Akturan and Tezcan, 2012; Masrek et al., 2012; Shih et al., 2010) cite m-banking as an innovative communication channel in that the customer interacts with a bank through a portable device. 
However, the dynamic markets for mobile devices and m-banking suggest the need for a fresh definition that captures recent advances in the field. Previous definitions have not, for example, explicitly stated which mobile devices qualify for use under the term mbanking. Nevertheless, accessing banking services from a laptop should not be considered mbanking, since their user interface is similar to that of desktop PCs. Laptops are aligned with the online/Internet banking category rather than with m-banking. This study accordingly proposes the following definition of m-banking:

A product or service offered by a bank or a microfinance institute (bank-led model) or MNO (non-bank-led model) for conducting financial and non-financial transactions using a mobile device, namely a mobile phone, smartphone, or tablet.

Cruz et al. (2010) identify the difference between m-banking and m-payments and argue that, if a bank is not directly involved in the instrumental gratification of a service offered, it is usually called a “mobile payment (m-payment)." Examples of such services include payments through overhead-priced SMS (e.g., ring tones) prepaid account loading (e.g., used for cinema tickets), or a charge made to the subscriber's account (e.g., credit card or invoicebased payment mechanism).

From the m-banking service perspective, the ecosystem depicted in Figure 1 comprises several applications, channels, and methods for conducting m-banking, as well as major services offered through m-banking channels.

"Please insert Figure 1 about here"

Retail and microfinance banks located in both developed and developing countries typically offer four points of access to m-banking services: (1) mobile applications that can be downloaded to a smartphone, (2) mobile browsers that can be used with any mobile or smartphone that has a Web browser, (3) applications that can be downloaded to a tablet, and (4) short messaging services (SMS) that provide notifications of account information. The 
first three routes require an Internet connection on the mobile device; SMS relies on standard Global System for Mobile Communication (GSM) networks. Overall, though, m-banking has changed the financial landscape, and portable devices are now considered ADCs that use different applications to deliver financial and non-financial services and products to consumers.

\section{Research methodology}

The literature search spanned 33 information systems, marketing, and business administration journals, as well as a few records of conference proceedings. To identify published articles pertaining to m-banking adoption, this search involved various databases (e.g., Science Direct, Emerald, IEEE, Inderscience, Taylor \& Francis, ACM, Wiley) and multiple relevant key terms, such as mobile banking (m-banking) adoption, mobile banking acceptance, mobile banking adoption intention, mobile banking adoption attitude, mobile banking usage behavior, mobile banking embracing, and mobile banking utilization. The identified articles represented a broad range of scientific, mostly peer-reviewed journals. In addition, the Google search engine revealed other articles that might not have been accessible in the online databases. Initial developments in this research field were heavily influenced by practitioners, so the literature review incorporates both academic sources (peer-reviewed journal publications, working papers, and conference papers) and practitioner sources (nonpeer-reviewed consultants' reports and surveys, official reports, journal articles, and other occasional papers) (Duncombe and Boateng, 2009). To ensure the inclusion of current developments, the period reviewed spanned January 2005-March 2014. The search resulted in 55 relevant publications, of which 48 (87\%) were published in scientific journals and seven (13\%) were conference publications. These various articles applied different research methods and referred to various geographic regions. Webster and Watson's (2002) 
classification focused on the model, theory, or framework they used; the constructs analyzed; the geographic location; and the research opportunities they proposed.

\section{Results}

The studies included in this review investigated and identified several influences on consumer adoption behavior toward m-banking. In general, they provided interesting insights into the diffusion pattern of m-banking. For most studies, the underlying objective was to discover deeper motivations and associations that significantly influenced potential adopters' attitudes and intentions across various social systems so that they could articulate behavioral intentions toward mobile banking adoption. Of the 55 studies included in this review, around two-thirds (65\%) were published from 2010-2012. No study was published in 2008, and only one appeared in 2005 and 2006, with one more in 2014 (see Table 3).

\section{"Insert Table 3 about here"}

Of the 33 journals that published articles on m-banking adoption, 27 (82\%) journals published only one article on m-banking services adoption from January 2005-March 2014. Further, the International Journal of Mobile Communications published the most articles (seven articles, or 13\%), followed by the International Journal of Bank Marketing (four, or 7\%), Computers in Human Behavior (three, or 6\%), the Journal of Internet Banking and Commerce (three, or 6\%), and then others combined (37, or 69\%).

The studies relied on different methods to collect their empirical data, including survey instruments and interviews, and triangulation was also evident. The average (mean) sample size was 365 consumers. Quantitative research was the most popular method: of 55 studies, 45 (82\%) used a quantitative (survey) method to collect data, and only three (5\%) employed qualitative methods such as interviews. In addition, five studies (9\%) used both qualitative and quantitative methods, and two studies were conceptual in nature. Among the most frequently investigated regions were Southeast Asia (e.g., Malaysia and Singapore), 
East Asia (e.g., Taiwan, China, and Korea), and Africa (e.g., Ghana, Zimbabwe, and South Africa); a few studies applied to Europe (e.g., Finland, Germany, and Turkey) and South Asia (e.g., India), as Figure 2 details. The geographic distribution reveals that, of these 55 studies, nine (16\%) were conducted in developed countries and the remaining 46 (84\%) in developing countries.

"Please insert Figure 2 about here"

During the review process, few constructs were identified that have not been covered in prior research but merit consideration. These constructs include consumer awareness (Dineshwar and Steven, 2013; Jain, 2013; Sharma, 2011), personal involvement (Zhou, 2012b), network externality (Zhou, 2012a), policy and regulatory frameworks (Thulani et al., 2011), experience, and religiosity (Amin and Ramayah, 2010).

\section{"Insert Table 4 about here"}

Analyzing the acceptance models used by these studies reveals a large and heterogeneous set. In total, 11 technological and social psychological adoption theories, models, and frameworks provided foundations for investigations of the consumer adoption of m-banking services. As Table 4 reveals, some authors used one specific adoption theory or an extension of it, such as the technology acceptance model (TAM) (e.g., Aboelmaged and Gebba, 2013; Chitungo and Munongo, 2013; Safeena et al., 2012), innovation diffusion theory (IDT) (e.g., Kim et al., 2009; Lin, 2011), or the unified theory of acceptance and use of technology (UTAUT) (e.g., Luo et al., 2010; Tan et al., 2010; Yu, 2012). Others combined different theories, such as TAM with the theory of planned behavior (Aboelmaged and Gebba, 2013); TAM and IDT (Ramdhony and Munien, 2013); UTAUT, IDT, and the ubiquitous computing framework (Saeed, 2011); or UTAUT with the task-technology fit (Zhou et al., 2010) model. In addition, a few authors (e.g., Laukkanen and Cruz, 2012; Zhou, 2011) have used self-developed models comprising various constructs. 
The results of these various studies suggest some guidance for how to increase mbanking adoption among the different population strata, living in both developed and developing countries (e.g., Saeed, 2011). Several recommendations include the development of dedicated marketing programs to create positive attitudes toward m-banking and to attract consumers (Wessels and Drennan, 2010). Marketers could emphasize m-banking's usefulness and compatibility with the consumers' lifestyles, though the design of the m-banking systems must also minimize the risk and cost that consumers face. Another recommendation places more emphasis on gaining consumers' trust by providing reliable, appropriate information (Lee and Chung 2009). In addition, a few studies offer guidelines with regard to prioritizing different antecedents and developing appropriate strategies to encourage adoption (e.g., Tan et al., 2010). Consumer segmentation (Koenig-Lewis et al., 2010), targeting marketing communication by gender (Riquelme and Rios, 2010), and seamlessly integrating mobile technology services and applications into ordinary banking activities (Yang, 2009) emerged among multiple marketing and business strategies that might encourage potential adopters and presumably increase m-banking adoption rates.

Multiple studies also attempt to identify antecedents of adoption. A particularly prominent antecedent is consumer trust in mobile banking, its associated applications, and the bank, according to several authors (e.g., Jain, 2013; Lee and Chung, 2009; Lin, 2011; Zhou, 2011). Some synergy between satisfaction and trust also emerged from a few studies that report that trust significantly affects the degree of satisfaction and is thus an important variable for m-banking environments (Lee and Chung, 2009). Furthermore, studies conducted in developing (but not developed) countries identify social and culture factors as strong influences on m-banking adoption (Alafeef et al., 2011; Bankole et al., 2011). Similarly, combining these factors with a range of demographic factors indicates that the impact of social and cultural features is significant (Crabbe et al., 2009). 
Several independent and dependent variables appear in investigations of varying aspects of consumer decision-making processes related to m-banking adoption. In particular, three main dependent variables (attitude, intention, and usage) and eight independent variables [perceived ease of use, perceived usefulness, trust, social influence, perceived risk, perceived behavioral control (or self-efficacy), compatibility with lifestyle and device, and facilitating conditions] emerged from this review. These contributions constitute the main research stream, as depicted in Table 5 and the Appendix.

Of these three dependent variables, a majority of the studies focus on the antecedents of behavioral intention (e.g., Luo et al., 2010; Teo et al., 2012; Zhou, 2011). Fewer studies investigate the antecedents of attitude (e.g., Akturan and Tezcan, 2012; Lin, 2011; Püschel et al., 2010). Only Crabbe et al. (2009) use all three dependent variables (attitude, intention, and use) to assess the impact of social and cultural factors on the adoption of m-banking in Ghana. They find that several independent variables, such as technology usage and services, exert positive influences on adopters but negative influences for non-adopters. In addition, perceived credibility and facilitating conditions affect attitudes toward m-banking adoption. In combination with a range of demographic factors, the impact of social and cultural features emerges as significant.

\subsection{Main theories}

The adoption of technology can be described in various ways. Some studies take a process approach and examine in-depth processes (e.g., Majchrzak et al., 2000); others focus on the relationships between technology adoption and influential variables, as exemplified by the UTAUT and the TAM (Im et al., 2011). The TAM is very popular as a framework for examining intentions to adopt m-banking. Of the 55 studies, 23 (42\%) used the TAM as their theoretical framework. This theory asserts that perceived usefulness and ease of use are fundamental determinants of system adoption and usage (Bankole et al., 2011); however, 
because the TAM excludes economic and demographic factors and external variables, it seemingly has limited use for explaining users' attitudes and behavioral intentions toward mobile service adoptions (Venkatesh and Davis, 2000). Therefore, among the 23 studies that have used TAM as their theoretical framework, many m-banking adoption studies extend or supplement the original TAM by including additional constructs, such as relative advantage and personal innovativeness (Chitungo and Munongo, 2013), perceived risk, perceived cost of use, compatibility with lifestyle and needs (Hanafizadeh et al., 2014), and perceived security (Hsu et al., 2011). Furthermore, the TAM omits any trust-based constructs related to e- or m-commerce and assumes that there are no barriers preventing a user from adopting an information system if he or she chooses to do so (Luarn and Lin, 2005).

Innovation diffusion theory, as developed by Rogers (1995), is the second most widely used model: nine studies (16\%) use IDT as their theoretical framework. According to this theory, the adoption rate of a new technology depends on five innovation characteristics: relative advantage, compatibility, complexity, observability, and trialability. Although IDT acknowledges a behavioral process, movement from awareness to acceptance, it does not explain how attitudes form and ultimately lead to acceptance or rejection, nor how innovation attributes fit the process (Bhattacherjee, 2000).

The third most common theory is UTAUT, as developed by Venkatesh et al. (2003). Of 55 studies, seven (13\%) use it. This theory focuses on the motivations for user behavior, such as perceived usefulness or relative advantage (Zhou, 2012b). As an extension of the TAM model, it is based on four factors: performance expectancy, effort expectancy, social influence, and facilitating conditions. The greatest limitation of UTAUT is that it does not include cultural factors (Im et al., 2011).

4.2 Main antecedents of attitude (ATT), intention (INT), and usage (USE) 
This review reveals the intriguing development and consolidation of antecedents used in prior research to study and analyze consumers' behavioral intentions toward m-banking. As many as 84 antecedents have been identified, as listed in the Appendix. Studies feature both descriptive and exploratory investigations and measures of the impact of the various constructs using different adoption theories and models. Among the identified antecedents, perceived ease of use (PEOU) and perceived usefulness (PU) are the most commonly used; approximately one-third of all m-banking adoption studies cite them. Other commonly used antecedents include trust, social influence, perceived risk, self-efficacy, compatibility, facilitating conditions, cost, credibility, culture, demographic factors, and structural assurance. Notably, more than $90 \%$ of the studies examine intention as their dependent variable, but intention has been used only two times to predict m-banking usage (Bankole et al., 2011; Crabbe et al., 2009). Finally, around half of the antecedents (55\%), as listed in the Appendix, have been tested only once.

To assess the significance of these antecedents for explaining attitude toward, intention to use, and usage of m-banking, we conducted a meta-analysis (see Table 5) of the ten most commonly used antecedents and calculated mean scores for the path coefficients for each relationship. Only constructs used in at least two different studies were included in this analysis. In total, eight studies use attitude as a dependent variable, 28 papers use intention, and as mentioned, only two articles use usage as their dependent variable.

"Please insert Table 5 about here"

As Table 5 shows, compatibility, PU, and PEOU have served as antecedents for both attitude and intention. The effect of compatibility on intention is the strongest, followed by the effect of PU and attitude. The effect of PU on attitude and intention generally is stronger than that of PEOU. Credibility, social influence, perceived behavioral control/self-efficacy, 
and perceived cost have on average a low to medium effect on intention to use m-banking services.

\subsection{Demographics}

A common interest in the studies included in this review is the analysis of user demographics (e.g., Laukkanen et al., 2007; Lee et al., 2005), including age, gender, and education, to predict m-banking adoption. The impact of demographics on the adoption of various electronic devices also has been extensively studied (Laukkanen and Cruz, 2012). According to Crabbe et al. (2009), demographic factors play a significant role in adoption decisions. They find that social and cultural factors, such as perceived credibility, facilitating conditions, perceived elitism, and demographic factors, significantly affect adoption decisions for m-banking in Ghana. Similarly, a survey conducted in Malaysia (Sulaiman et al., 2007) reveals that both demographic and psychographic variables affect the adoption of new innovations such as m-banking — in particular, age, gender, personal income, and education. Finally, in their investigation of the influence of demographic factors on the adoption of m-banking and its applications, Teo et al. (2012) also incorporate demographic factors and subjective norms with the TAM to assess intentions to adopt in Malaysia. They extend the TAM with four demographic factors (gender, age, education, and income) and subjective norms and thus reveal that education and income had positive relationships with PU, whereas gender and education related positively to PEOU.

\section{Conclusion}

This study provides a systematic review of literature on m-banking adoption published from January 2005-March 2014. The 55 relevant studies appear in 48 journal articles and seven conference proceedings and represent a reasonably deep view of the field of m-banking acceptance research. Since 2009, both empirical and conceptual research activities have increased and appear likely to grow increasingly pervasive. However, this 
literature review also shows that existing research is fragmented, constituted by various theoretical frameworks, with relatively small sample sizes (average $\mathrm{N}=365$ ) drawn from both developed and developing countries. Furthermore, it mostly depends on the TAM and its modifications to explain intentions to use m-banking. An analysis of the conceptual models expressly acknowledged in these studies reveals a large and heterogeneous sample, consisting of 11 models, theories, or frameworks used to study different constructs, attributes, and factors that lead to m-banking adoption. In addition, many of the studies in our sample provide customized research models that feature both internal and external factors.

Accenture (2013) reports that, in developing countries one form of m-banking, i.e. mpayments, is gaining a strong foothold. However, as an emerging service, the use of mobile phones to conduct banking transactions and access other financial information (especially in mature markets) has not been widely adopted (Juniper Research, 2013). In acknowledging this problem, studies have examined consumer behavioral intentions toward the adoption of m-banking using various antecedents. Impediments to acceptance or adoption have been investigated mainly using quantitative methods in studies that refer to a wide variety of influences on the acceptance of m-banking and other products offered by various banks, microfinance institutions, and mobile operators.

However, several dependent and independent variables can be identified as prominent in investigations of the consumer decision-making process for m-banking. For example, most research includes two main dependent variables (attitude and intention) and eight independent variables (perceived ease of use, perceived usefulness, trust, social influence, perceived risk, perceived behavioral control (or self-efficacy), compatibility with lifestyle and device, and facilitating conditions) that seemingly define the main research stream.

Furthermore, the results reveal that compatibility, PU, and attitude are the most significant drivers of intentions toward using m-banking. 
Finally, extant research has focused almost entirely on SMS banking, without addressing more developed m-banking, such as applications. This choice has limited the contributions to current knowledge. To suggest further research directions, this review also consolidates the antecedents already used to study consumer behavioral intentions.

\subsection{Limitations}

Some limitations of this review offer opportunities for additional research. First, the review centers on research pertaining to consumer acceptance or adoption of m-banking, but m-banking is vast in scope, comprising aspects such as infrastructure, technology, and innovation. It also offers both growth potential and potential pitfalls. Incorporating all these aspects of m-banking into future literature reviews would be useful for delineating the evolving banking channel. Second, the acceptance or adoption of m-banking is the core of this study, so it excluded factors that prompt post-adoption usage or consumers' continuous intentions to use m-banking. Third, although m-banking and m-payments are two important components of mobile financial applications (Mallat et al., 2004), the literature search was conducted with the key term 'm-banking', so excluding the scant specific literature on mpayments from the primary scope. However, as most of the studies reviewed did not distinguish between m-banking and m-payments, our literature review is limited in that it was impossible to scrutinize specific categories of m-banking, such as m-payments. Similarly, studies specifically discussing factors that might prevent the adoption of m-banking were also considered beyond the scope of this study. Fourth, the literature search focused on m-banking acceptance or adoption, which might have led to the exclusion of some important and relevant articles. Fifth, despite clear reasons to commence the review in January 2005, mbanking (such as SMS banking) also existed before that point.

\subsection{Further research}


The following recommendations for research derive partly from the directions, recommendations, and suggestions mentioned in the reviewed studies, as well as from the analysis of the results of the present study. For example, most studies of consumer behavior in m-banking are cross-sectional in nature or limited to a single demographic location such that they measure the perceptions and intentions of consumers at a single point in time. As a result, it is not possible to elicit extensive generalizations from their conclusions. In addition, most studies have limited their data collection to a single country, using banking as a test bed. To overcome such common limitations, several areas offer the potential to deliver additional and relevant insights.

\subsubsection{Research design}

In emphasizing the need for qualitative research, more studies should use unstructured interviews to analyze consumer behavioral intentions toward m-banking adoption. To improve the quality and relevance of their studies, researchers might collect more empirical data, supported by different guiding theories, to clarify adoption patterns across a range of consumers. Combinations of qualitative and quantitative approaches also might effectively test these conceptual models and investigate semantic relationships among the factors or constructs applied. This recommendation is based on the recognition that prior research mostly has used survey instruments to collect data and test hypotheses.

\subsubsection{Transnational and cross-cultural studies}

M-banking is a worldwide phenomenon; studies that undertake a comparative analysis of developed and developing economies using different models and approaches could produce meaningful insights into the behavior and attitudes of participants. As suggested by Crabbe et al. (2009), cross-cultural and transnational studies would enable researchers to determine how specific social and cultural characteristics of a society influence the adoption of technologies and services among its members. A quick overview of the 55 studies included 
in this review suggests that only three (Laukkanen and Cruz, 2012; Bankole and Cloete, 2011; Medhi et al., 2009) are transnational. A comparative analysis of m-banking adoption by stakeholders living in rural and urban areas is also necessary; no prior study has addressed this critical aspect. Many researchers have highlighted the need for broad-based, large-scale, longitudinal studies of m-banking adoption, and it follows that eliminating short-term effects by considering a more representative sample over time would extend understanding.

\subsubsection{Ethnographic studies}

Following initiatives in developed countries, most developing countries recently have started creating unique, customized, dedicated m-banking solutions for their consumers. For example, the Philippines (G-Cash) and Pakistan (easypaisa) have introduced innovative services to meet the banking needs of consumers who live in remote, rural areas and have little or no access to the formal banking system. Ethnographic research in these countries would likely provide valuable insights into adoption by local consumers.

\subsubsection{Microfinance institutions}

If it is defined to include microfinance institutions, the m-banking sphere has opened new investment and innovation opportunities and expanded the scope of banking to serve low-income markets. However, most studies focus on banking contexts, leaving substantial scope for exploring the integration of microfinance with m-banking. Creating an m-banking culture, particularly in developing economies, may produce differentiated findings and potentially help microfinance institutions to develop future marketing plans with a better understanding of their consumers' preferences and choices.

\subsubsection{M-banking adoption from service providers' and network carriers' perspectives}

Explorations of m-banking adoption from the perspective of service providers, such as software houses, MNOs, IT solution providers, or network carriers, would be welcome. As indicated by Accenture (2013), "m-payments bridge the telco industry to other industries 
from banking and financial services to consumer goods and the public sector.” Industry convergence offers new opportunities for the different players in the m-banking ecosystem, an aspect not yet examined in m-banking literature.

\subsubsection{Development of legal and regulatory frameworks}

Considering the enormous benefits associated with m-banking, such as providing financial services to unbanked communities, reducing banks' operating costs, providing new growth opportunities, and enabling new innovations in financial services, many countries have formalized m-banking by introducing regulatory frameworks. Further studies of these frameworks could prove valuable. Moreover, most consumers probably are not aware of the presence of such legal or regulatory frameworks governing the products or services they use. Investigating consumer awareness and understanding in this area would be worthwhile.

\subsubsection{Research on smartphone and tablet PC users}

Surprisingly, no study has explicitly investigated the behavior of smartphone or tablet users in relation to m-banking. Because users of smartphones and tablets adopt applications provided by their banks to access m-banking, they might differ considerably in their attitudes and intentions toward m-banking. Therefore, it would be interesting to investigate issues such as continued intentions to use among this particular subset of consumers.

\subsubsection{Relationship between m-banking, m-payments and electronic payments}

Another critical theme for future research is to understand the relationship between mbanking, m-payments, and electronic payments. As argued by Dahlberg et al. (2008), the relationships between these technologies and services are unclear and there is still some confusion about whether these are just a new access channel serving existing services, or a new payment instrument, or both. Studies examining this question would add value to the existing literature. 


\section{References}

Aboelmaged, M.G., Gebba, T. R., 2013. Mobile banking adoption: an examination of technology Acceptance model and theory of planned behavior. International Journal of Business Research and Development 2(1), 35 - 50.

Accenture, 2013. Mobile Web Watch 2013: The New Persuaders. Available at http://www.accenture.com/SiteCollectionDocuments/PDF/Technology/accenturemobile-web-watch-2013-survey-new-persuaders.pdf (accessed January 1, 2014)

Akturan, U., Tezcan, N., 2012. Mobile banking adoption of the youth market: Perceptions and Intentions. Marketing Intelligence \& Planning 30(4), 444 - 459.

Alafeef, M., Singh, D., Ahmad, K., 2011. Influence of demographic factors on the adoption level of mobile banking applications in Jordan. Research Journal of Applied Sciences 6(6), $373-377$.

Alafeef, M., Singh, D., Ahmad, K., 2012. The influence of demographic factors and user interface on mobile banking adoption: A review. Journal of Applied Sciences 12(20), $2082-2095$.

Amin, H., Hamid, M.R.A., Tanakinjal, G.H., Lada, S., 2006. Undergraduate attitudes and expectations for mobile banking. Journal of Internet Banking and Commerce 11(3), 1 10.

Amin, H., and Ramayah, T., 2010. SMS banking: explaining the effects of attitude, social norms and perceived security and privacy. The Electronic Journal on Information Systems in Developing Countries 41(2), 1 - 15.

Amin, H., Supinah, R., Aris, M. M., Baba, R. 2012. Receptiveness of mobile banking by Malaysian local customers in Sabah: an empirical investigation. Journal of Internet Banking \& Commerce 17(1). 1 - 12. 
Amin, H., Baba, R., Muhammad, M. Z. 2007. An analysis of mobile banking acceptance by Malaysian customers. Sunway Academic Journal 4, 1 - 12.

Bankole, F. O., Bankole, O. O., Brown, I., 2011. Mobile banking adoption in Nigeria. The Electronic Journal on Information Systems in Developing Countries 47(2), 1 - 23. Bankole, O., Cloete, E., 2011. Mobile banking: A comparative study of South Africa and Nigeria. Proceedings of the IEEE Africon, Livingstone, Zambia, 2011.

Barati, S., Mohammadi, S. 2009, October. An efficient model to improve customer acceptance of mobile banking. Proceedings of World Congress on Engineering and Computer Science (Vol. 2, pp. 20-22),San Francisco, USA.

Bhattacherjee, A., 2000. Acceptance of e-commerce services: the case of electronic brokerages. IEEE Transactions on Systems, Man and Cybernetics, Part A: Systems and Humans 30(4), $411-420$.

Chitungo, S. K., Munongo, S., 2013. Extending the technology acceptance model to mobile banking adoption in rural Zimbabwe. Journal of Business Administration and Education 3(1), 51 - 79.

Chung, N., Kwon, S. J., 2009. Effect of trust level on mobile banking satisfaction: A multigroup analysis of information system success instruments. Behaviour \& Information Technology 28(6), $549-562$.

Crabbe, M., Standing, C., Standing, S., Karjaluoto, H., 2009. An adoption model for mobile banking in Ghana. International Journal of Mobile Communications 7(5), 515 - 543.

Cruz, P., Neto, L. B. F., Muñoz-Gallego, P., Laukkanen, T., 2010. Mobile banking rollout in emerging markets: evidence from Brazil. International Journal of Bank Marketing 28(5), $342-371$. 
Dahlberg, T., Mallat, N., Ondrus, J., Zmijewska, A., 2008. Past, present and future of mobile payments research: A literature review. Electronic Commerce Research and Applications, 7(2), $165-181$.

Dineshwar, R., Steven, M., 2013. An investigation on mobile banking adoption and usage: A case study of Mauritius. Proceedings of the 3rd Asia-Pacific Business Research Conference, Kuala Lumpur, Malaysia, 2013.

Donner, J., Tellez, C.A., 2008. Mobile banking and economic development: Linking, adoption, impact, and use, Asian Journal of Communication 18(4), 318 - 332.

Duncombe, R., Boateng, R., 2009. Mobile phones and financial services in developing countries: A review of concepts, methods, issues, evidence and future research directions. Third World Quarterly 30(7), 1237 - 1258.

Gu, J., Lee, S., Suh, Y., 2009. Determinants of behavioral intention to mobile banking. Expert Systems with Applications 36 (9), 11605 - 11616.

Hanafizadeh, P., Behboudi, M., Koshksaray, A.A., Tabar, M.J.S., 2014. Mobile-banking adoption by Iranian bank clients. Telematics and Informatics 31 (1), 62 - 78.

Harma, M.K., Dubey, R., 2009. Prospects of technological advancements in banking sector using mobile banking and position of India. Proceedings of the International Association of Computer Science and Information Technology Spring Conference, Singapore, 2009.

Hsu, C., Wang, C., Lin, J.C., 2011. Investigating customer adoption behaviors in mobile financial services. International Journal of Mobile Communications 9(5), 477 - 494.

Huili, Y., Shanzhi, L., Yinghui, Y., 2013. A study of user adoption factors of mobile banking services based on the trust and distrust perspective. International Business and Management 6(2), 9-14. 
Im, I., Hong, S., Kang, M. S., 2011. An international comparison of technology adoption: Testing the UTAUT model. Information \& Management 48(1), 1 - 8.

International Telecommunication Union, 2011. ICT Facts and Figures: The world in 2011. Available at www.itu.int/ITU-D/ict/facts/2011/material/ ICTFactsFigures2011.pdf (accessed Janury 1, 2014)

Ivatury, G., Mas, I., 2008. The early experience with branchless banking. CGAP Focus Note, No. 46, 2008. Available at http://ssrn.com/abstract=1655257 (accessed January 1, 2014)

Jain, Y., 2013. Mobile banking: A study on adoption \& challenges in southern Rajasthan, India. International Journal of Innovative Research \& Development 2(4), 902 - 914.

Juniper Research, 2013. Mobile banking handset \& tablet market strategies 2013-2017, Available at http://www.juniperresearch.com/reports/mobile_banking (accessed January 1, 2014).

Khraim, H. S., AL Shoubaki, Y. E., Khraim, A. S., 2011. Factors affecting Jordanian consumers' adoption of mobile banking services. International Journal of Business and Social Science 2(20), 96 - 105.

Kim, G., Shin, B., Lee, H.G., 2009. Understanding dynamics between initial trust and usage intentions of mobile banking. Information Systems Journal 19 (3), 283 - 311.

Koenig-Lewis, N., Palmer, A., Moll, A., 2010. Predicting young consumers' take up of mobile banking services. International Journal of Bank Marketing 28(5), 410 - 432.

Laukkanen, T., Cruz, P., 2012. Cultural, individual and device-specific antecedents on mobile banking adoption: A cross-national study. Proceedings of the 45th IEEE Hawaii International Conference on System Sciences (HICSS), Hawaii.

Laukkanen, T., Sinkkonen, S., Kivijarvi, M., Laukkanen, P., 2007. Innovation resistance among mature consumers. Journal of Consumer Marketing 24(7), 419 - 427. 
Lee, E., Kwon, K., Schumann, D., 2005. Segmenting the non-adopter category in the diffusion of internet banking. International Journal of Bank Marketing 23(5), 414 437.

Lee, K.C., Chung, N., 2009. Understanding factors affecting trust in and satisfaction with mobile banking in Korea: A modified DeLone and McLean's model perspective. Interacting with Computers 21(5), 385 - 392.

Lin, H., 2011. An empirical investigation of mobile banking adoption: The effect of innovation attributes and knowledge-based trust. International Journal of Information Management 31(3), $252-260$.

Liu, Z., Min, Q., Ji, S., 2009. An empirical study on mobile banking adoption: The role of trust. Proceedings of the 2nd IEEE International Symposium on Electronic Commerce and Security, Nanchang, China.

Luarn, P., Lin, H., 2005.Toward an understanding of the behavioral intention to use mobile banking. Computers in Human Behavior 21(6), 873 - 891.

Luo, X., Li, H., Zhang, J., Shim, J.P., 2010. Examining multi-dimensional trust and multifaceted risk in initial acceptance of emerging technologies: An empirical study of mobile banking services. Decision Support Systems 49(2), 222 - 234.

Majchrzak, A., Rice, R. E., Malhotra, A., King, N., Ba, S., 2000. Technology adaption: the case of a computer-supported inter-organizational virtual team 1. MIS Quarterly 24(4), $569-600$.

Mallat, N., Rossi, M., Tuunainen, V. K., 2004. Mobile banking services. Communications of the ACM, 47(5), $42-46$.

Masrek, M.N., Omar, N., Uzir, N.A., Khairuddin, I.E., 2012. The impact of technology trust on mobile banking utilization. Science Series Data Report 4(12), 27 - 36. 
Medhi, I., Ratan, A., Toyama, K., 2009. Mobile-banking adoption and usage by low-literate, low-income users in the developing world. In N. Aykin (Ed.), Internationalization, design and global development. Lecture notes in computer science, Berlin Heidelberg, Germany: Springer 5623, 485 - 494.

Mohd Daud, N., Kassim, M., Ezalin, N., Said, M., Wan, W. S. R., Mohd Noor, M. M. 2011. Determining critical success factors of mobile banking adoption in Malaysia. Australian Journal of Basic \& Applied Sciences 5(9), 252 - 265.

Püschel, J., Mazzon, J. A., Hernandez, J. M. C., 2010. Mobile banking: Proposition of an integrated adoption intention framework. International Journal of Bank Marketing 28(5), $389-409$.

Raleting, T., Nel, J., 2011. Determinants of low-income non-users' attitude towards WIG mobile phone banking: Evidence from South Africa. African Journal of Business Management 5(1), $212-223$.

Ramdhony, D., Munien, S. 2013. An Investigation on Mobile Banking Adoption and Usage: A Case Study of Mauritius. World Journal of Social Sciences 3(3), 197 - 217.

Rao Hill, S., Troshani, I. 2010. Factors influencing the adoption of personalisation mobile services: empirical evidence from young Australians. International Journal of Mobile Communications 8(2), $150-168$.

Ravendran, R., MacColl, I., Docherty, M., 2012. Tag-based interaction in online and mobile banking: A preliminary study of the effect on usability. Proceedings of the 10th Asia Pacific Conference on Computer Human Interaction (APCHI), Matsue-city, Shimane, Japan.

Riquelme, H. E., and Rios, R. E., 2010. The moderating effect of gender in the adoption of mobile banking. International Journal of Bank Marketing 28(5), 328 - 341.

Rogers, E., 1995. Diffusion of innovations (4th ed.), New York: Free Press. 
Saeed, K., 2011. Understanding the adoption of mobile banking services: An empirical assessment. Proceedings of the 7th Americas Conference on Information Systems, Detroit, Michigan.

Safeena, R., Date, H., Kammani, A., Hundewale, N., 2012. Technology adoption and Indian consumers: Study on mobile banking. International Journal of Computer Theory and Engineering 4(6), 1020 - 1024.

Saleem, Z., Rashid, K., 2011. Relationship between customer satisfaction and mobile banking adoption in Pakistan. International Journal of Trade, Economics and Finance 2(6), 537 $-544$.

Schierz, P. G., Schilke, O., Wirtz, B. W., 2010. Understanding consumer acceptance of mobile payment services: An empirical analysis. Electronic Commerce Research and Applications 9(3), $209-216$.

Shaikh, A.A., 2013. Mobile banking adoption issues in Pakistan and challenges ahead. Journal of the Institute of Bankers Pakistan 80(3), 12 - 15.

Sharma, A., 2011. Mobile banking as technology adoption and challenges. International Journal of Multidisciplinary Research 1(6), 147 - 157.

Shen, Y., Huang, C., Chu, C., Hsu, C., 2010. A benefit-cost perspective of the consumer adoption of the mobile banking system. Behavior \& Information Technology 29(5), 497 $-511$.

Sheng, M., Wang, L., Yu, Y. 2011, October. An Empirical Model of Individual Mobile Banking Acceptance in China. Proceedings of the Computational and Information Sciences (ICCIS) (pp. 434-437). IEEE.

Shih, K., Hung, H., Lin, B., 2010. Assessing user experiences and usage intentions of mbanking service. International Journal of Mobile Communications 8(3), 257 - 277. 
Sulaiman, A., Jaafar, N.I., Mohezar, S., 2007. An overview of mobile banking adoption among the urban community. International Journal of Mobile Communications 5(2), $157-168$.

Tan, K. S., Chong, S.C., Loh, P.L., Lin, B., 2010. An evaluation of e-banking and m-banking adoption factors and preference in Malaysia: A case study. International Journal of Mobile Communications 8(5), 507 - 527.

Teo, A., Tan, G.W., Cheah, C., Ooi, K., Yew, K., 2012. Can the demographic and subjective norms influence the adoption of mobile banking? International Journal of Mobile Communications 10(6), 578 - 597.

Thulani, D., Kosmas, N., Collins, M., Lloyd, C., 2011. Adoption and use of SMS/mobile banking services in Zimbabwe: an exploratory study. Journal of Internet Banking and Commerce 16(2), 1 - 15.

Tobbin, P., 2012. Towards a model of adoption in mobile banking by the unbanked: A qualitative study. Info 14(5), $74-88$.

Veijalainen, J., Terziyan, V., Tirri, H., 2006. Transaction management for m-commerce at a mobile terminal. Electronic Commerce Research and Applications 5(3), 229 - 245.

Venkatesh, V., Davis, F.D., 2000. A theoretical extension of the technology acceptance model: Four longitudinal field studies. Management Science 46(2), 186 - 204.

Venkatesh, V., Morris, M. G., Davis, G.B., Davis, F. D., 2003. User acceptance of information technology: Toward a unified view. MIS Quarterly 27(3), 425 - 478.

Webster, J., Watson, R., 2002. Analyzing the past to prepare for the future: Writing a literature review. MIS Quarterly 26(2), 13 - 23.

Wessels, L., Drennan, J., 2010. An investigation of consumer acceptance of m-banking. International Journal of Bank Marketing 28(7), 547 - 568. 
Yang, A. S., 2009. Exploring adoption difficulties in mobile banking services. Canadian Journal of Administrative Sciences 26(2), 136 - 149.

Yu, C., 2012. Factors affecting individuals to adopt mobile banking: Empirical evidence from the UTAUT model. Journal of Electronic Commerce Research 13(2), 104 - 121.

Zhou, T., 2011. An empirical examination of initial trust in mobile banking. Internet Research 21(5), 527 - 540.

Zhou, T., 2012a. Examining mobile banking user adoption from the perspectives of trust and flow experience, Information Technology Management 13(1), 27 - 37.

Zhou, T., 2012b. Understanding users' initial trust in mobile banking: An elaboration likelihood perspective. Computers in Human Behavior 28(4), 1518 - 1525.

Zhou, T., Lu, Y., Wang, B., 2010. Integrating TTF and UTAUT to explain mobile banking user adoption. Computers in Human Behavior 26(4), 760 - 767. 
Highlights:

- Literature review analyses research on mobile banking adoption

- Analysis indicates that $\mathbf{m}$-banking research lacks a clear roadmap

- Literature focuses on SMS banking in developing countries

- m-banking adoption literature mostly utilizes technology acceptance model

- Compatibility (with lifestyle and device), perceived usefulness, and attitude are the most significant drivers of intention 
Figure 1. m-banking Applications, Channels and Services

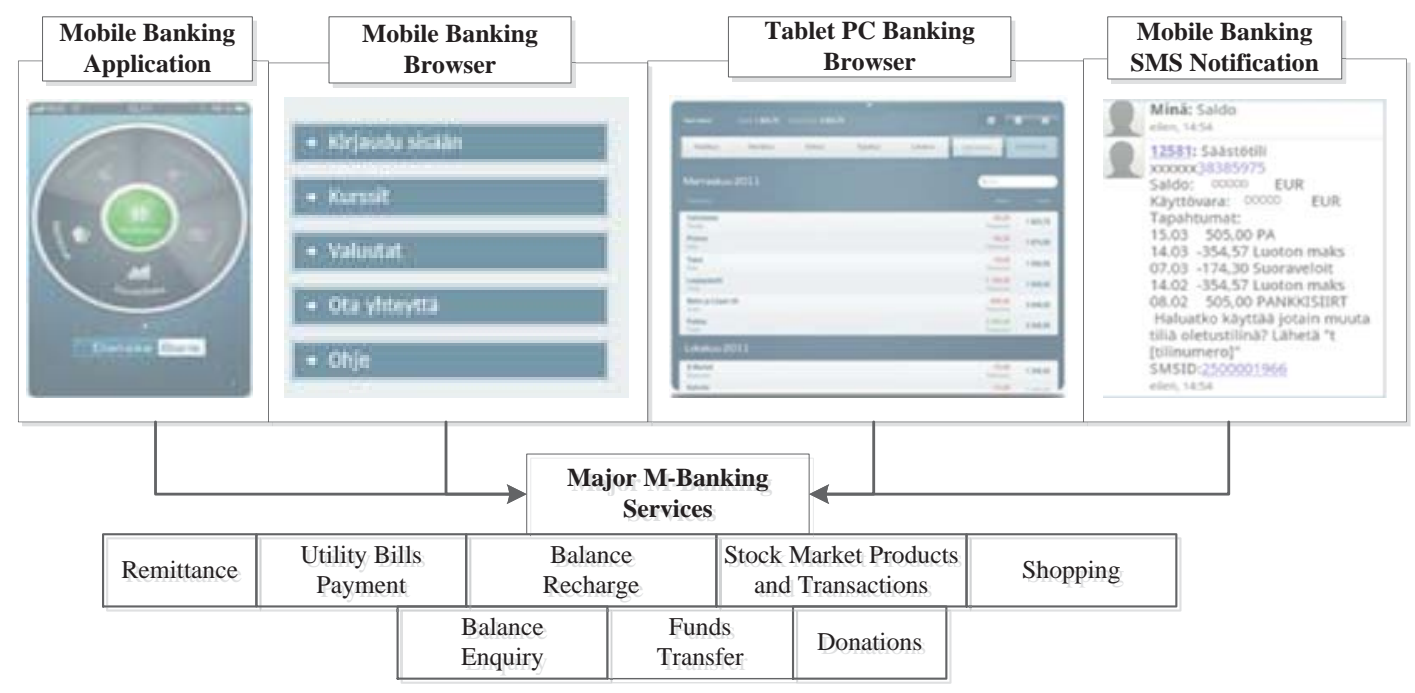


Figure 2. Scope and Focus of Literature on m-banking Adoption

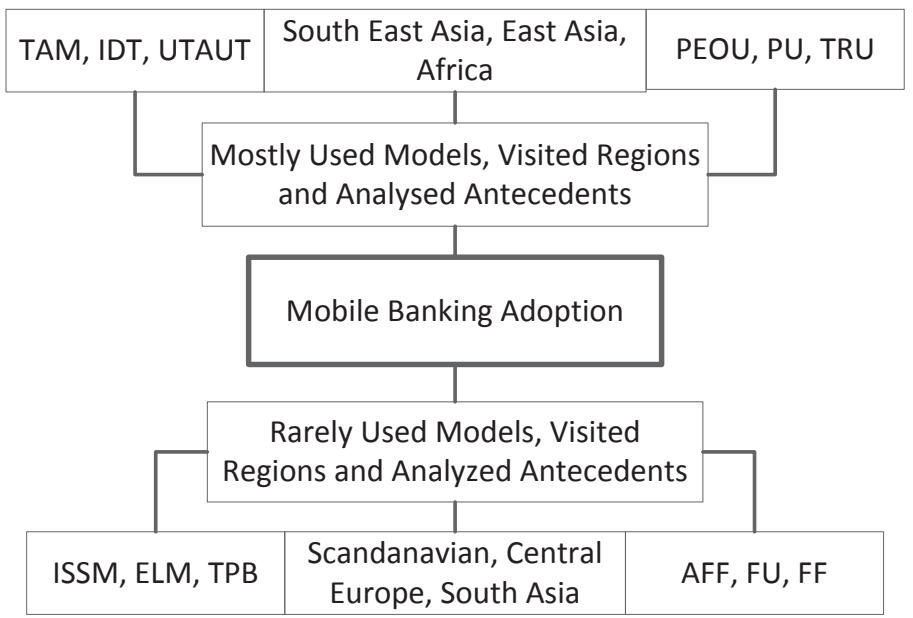


Table 1. m-Banking Users (International Telecommunication Union, 2012)

\begin{tabular}{lcc}
\hline Global population & 7.100 billion & $100 \%$ \\
Mobile phone subscription & 6.835 billion & $96 \%$ \\
m-Banking accounts/users & 0.590 billion & $\mathbf{8 . 6 \%}$
\end{tabular}


Table 2. Main services offered through m-banking

\begin{tabular}{ll}
\hline Financial services & Non-financial services \\
\hline Bill payments & Balance enquiry \\
Peer-to-peer payments & Mini-bank statement \\
Fund transfers & PIN change \\
Remittance & Checkbook request \\
Shopping and donations & Due alerts for payments \\
Mobile balance recharge & Locate ATMs \\
\hline
\end{tabular}




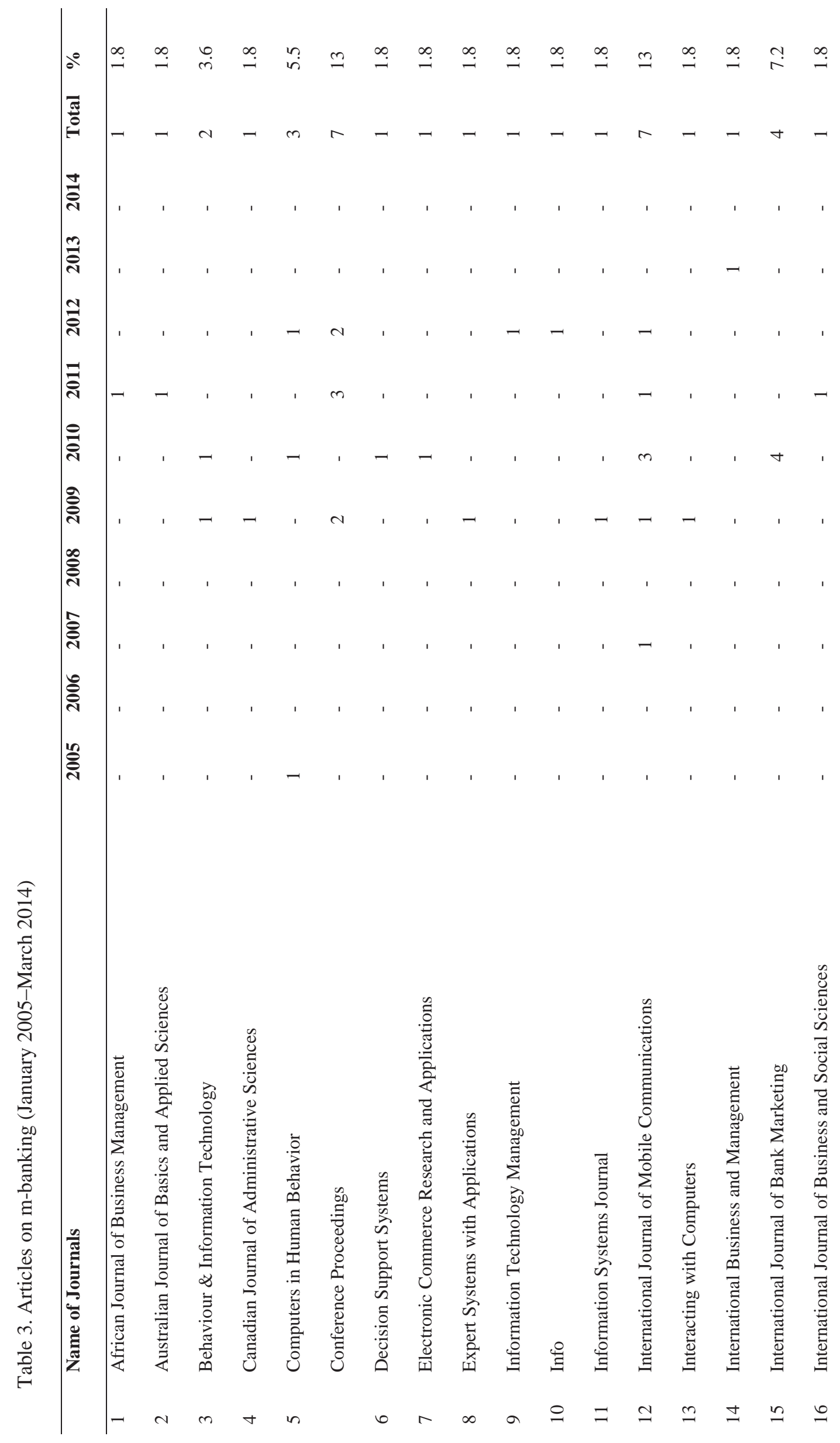




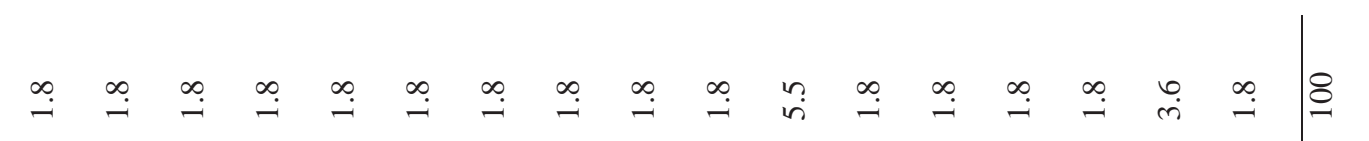

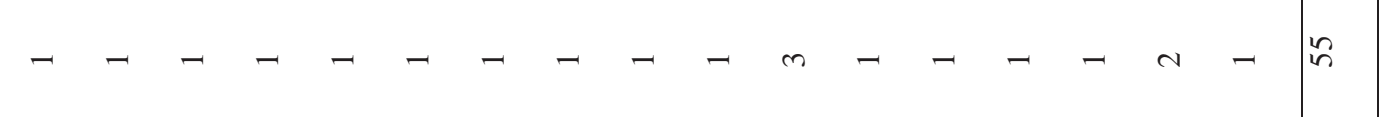

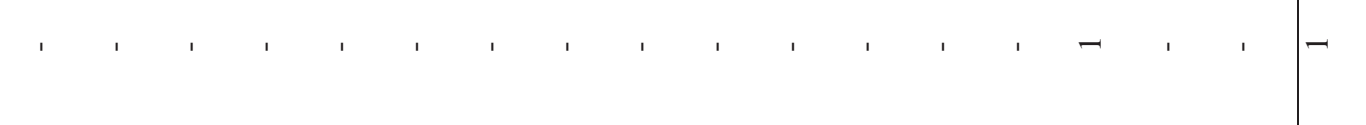

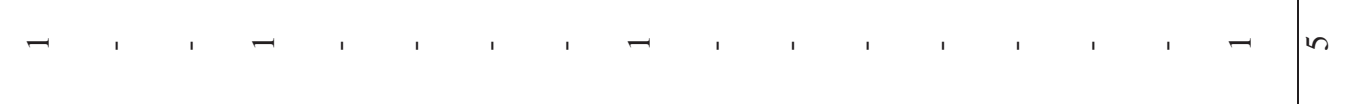

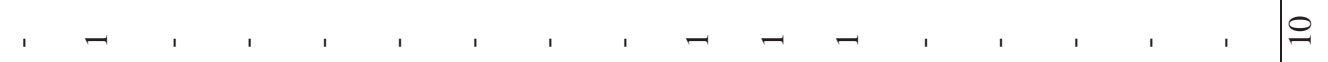

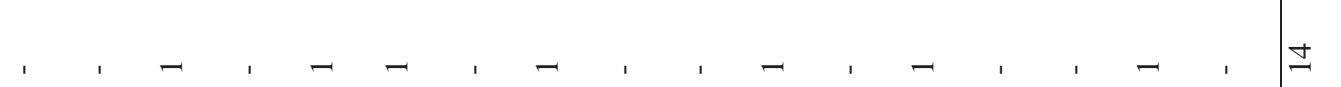
$1,1,1,1,1,1,1,1,1,1,1,1,1$

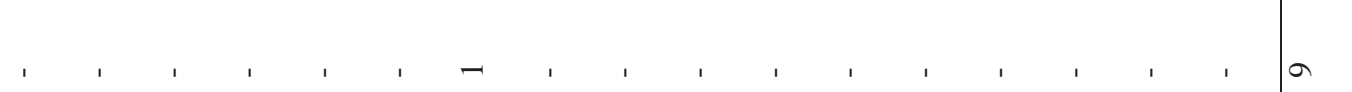

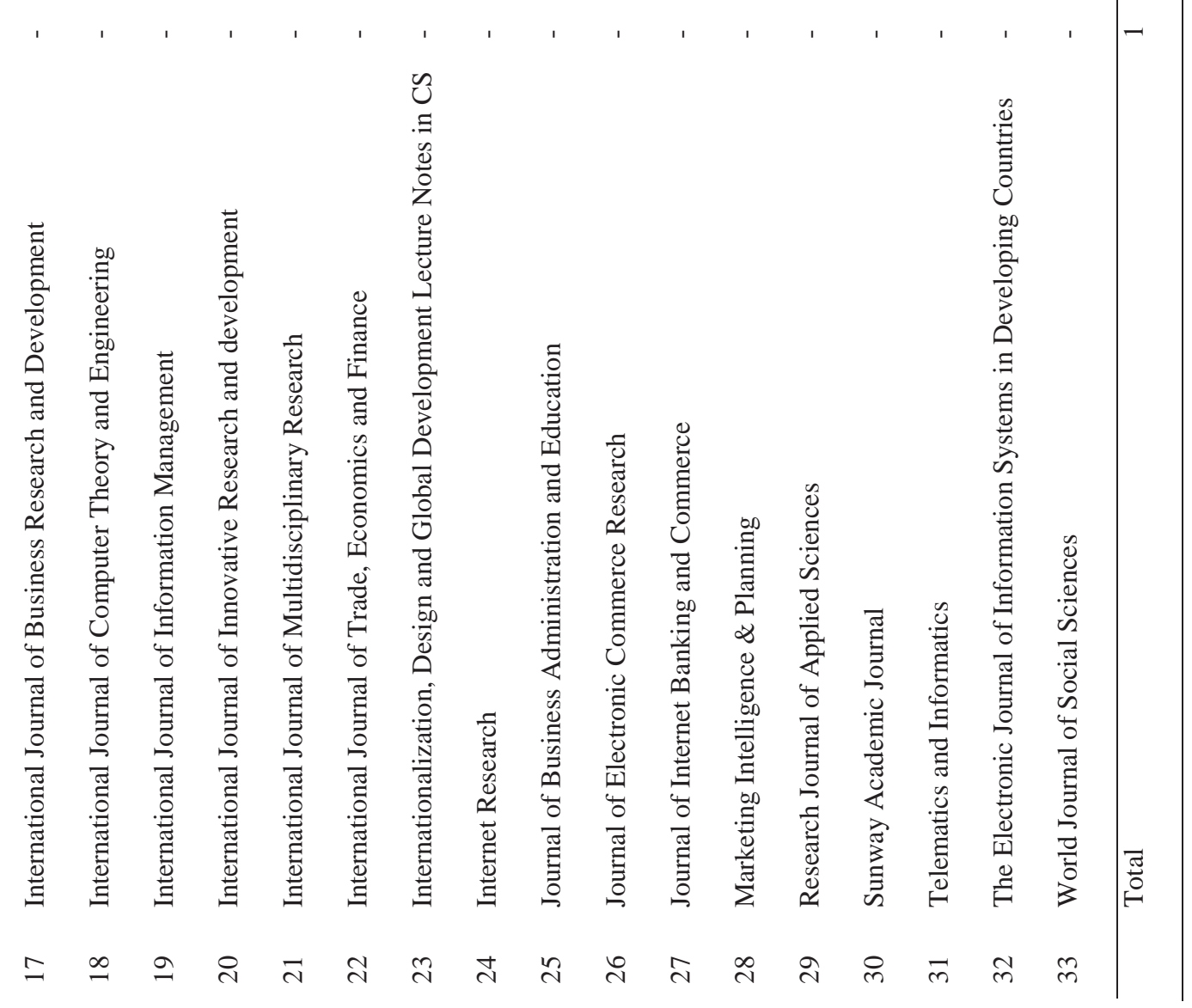




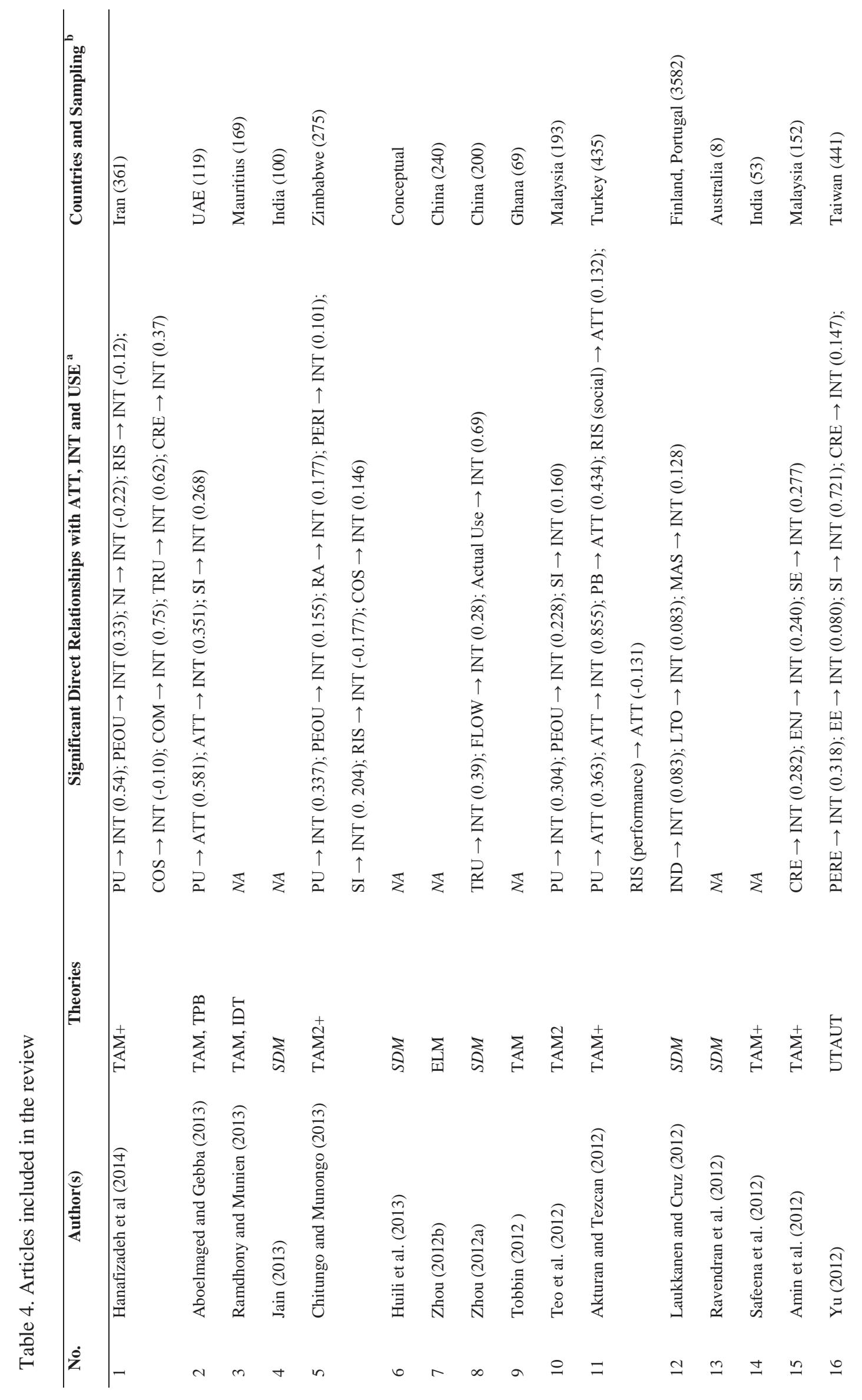




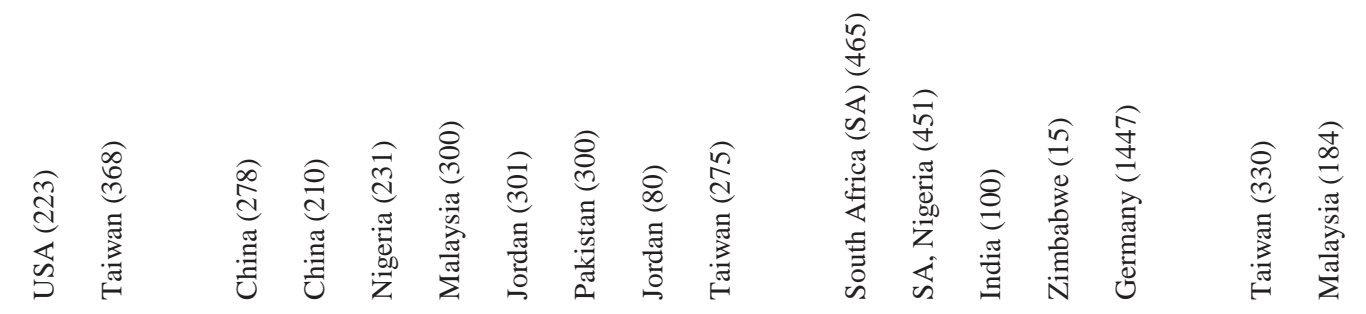

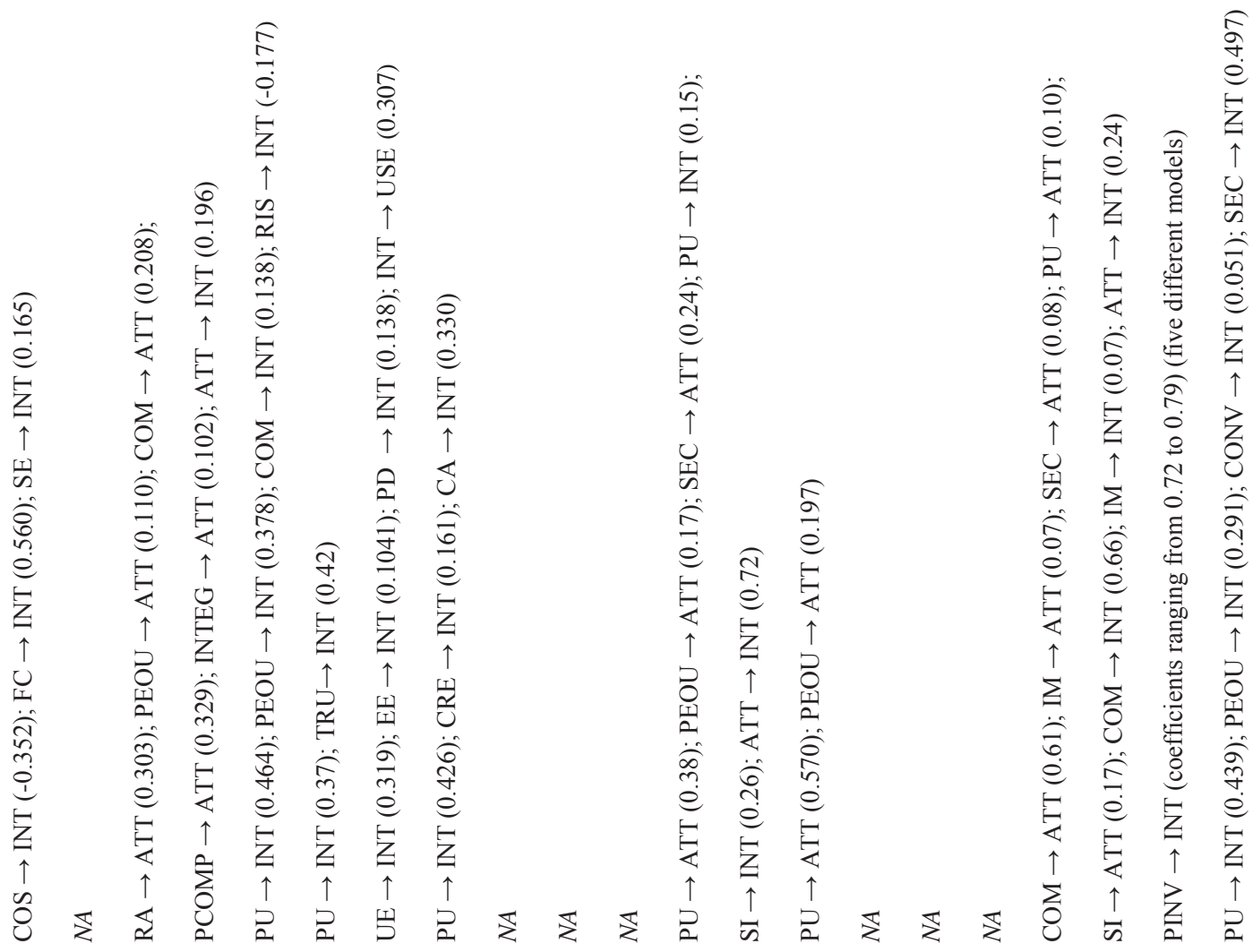

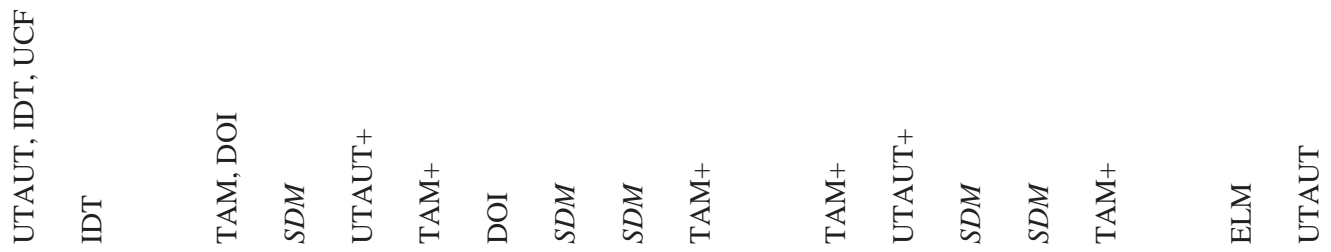

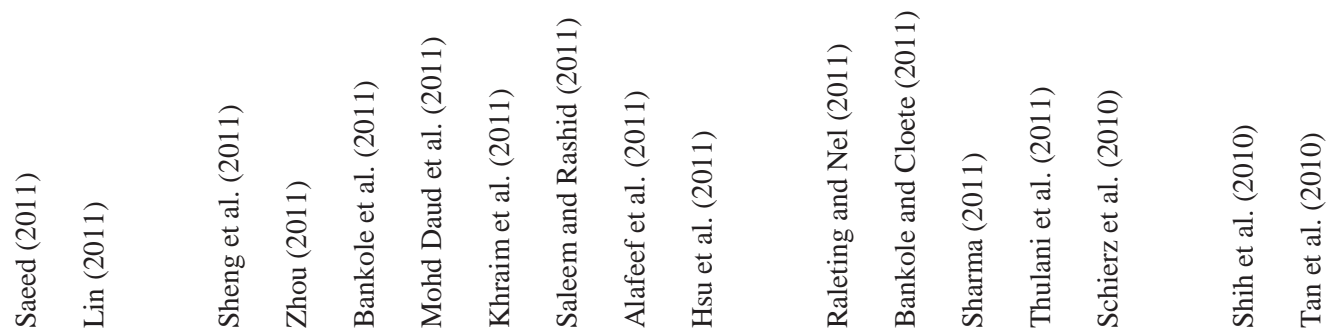

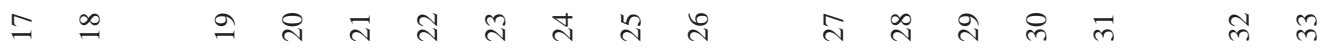




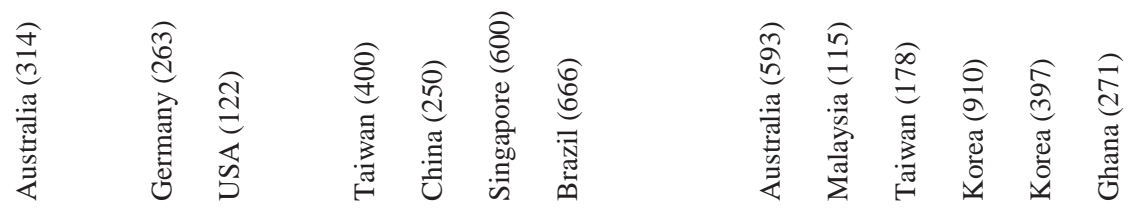

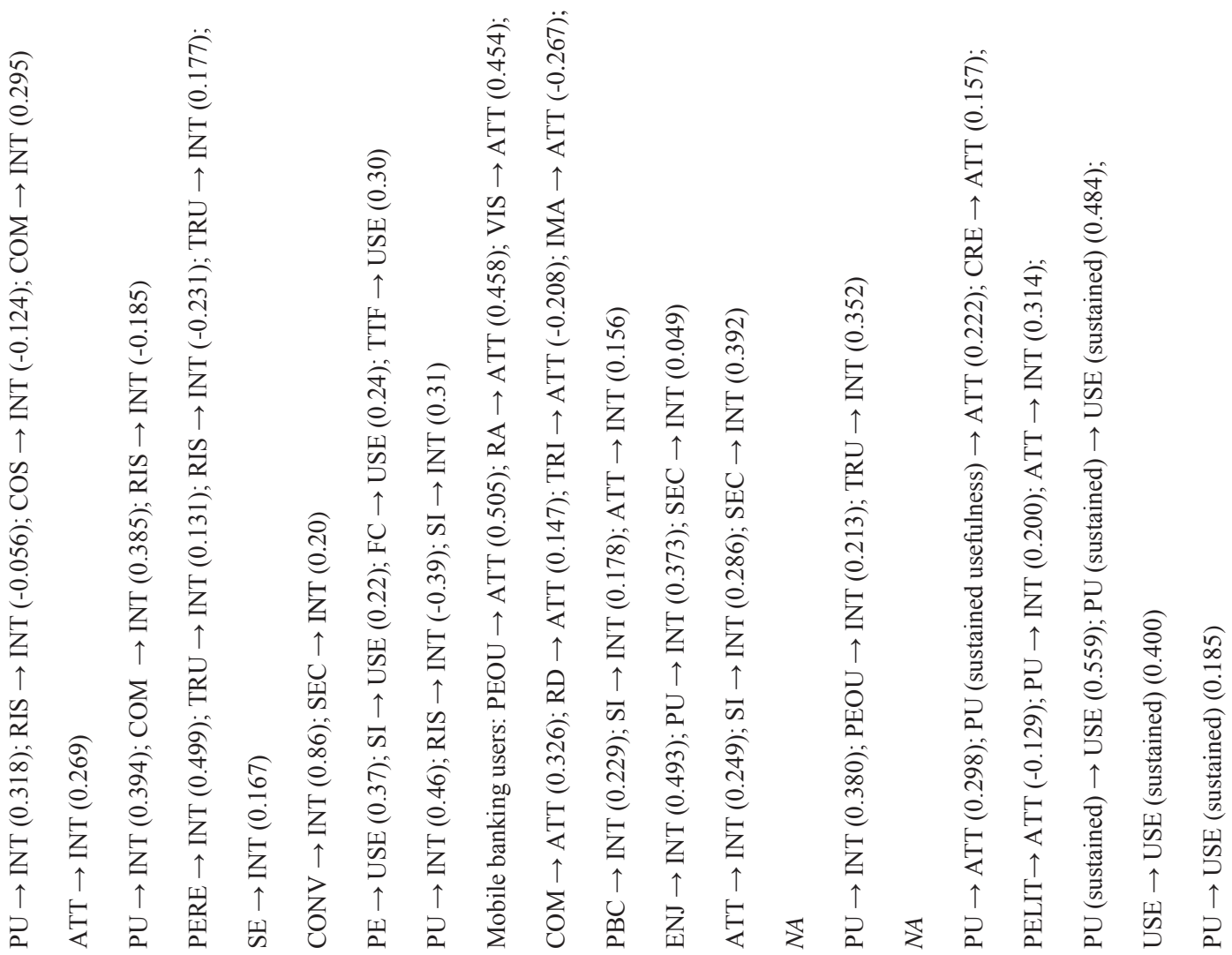

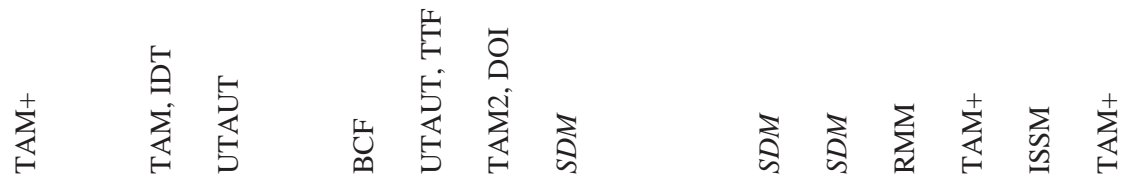

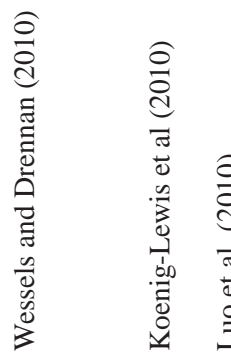

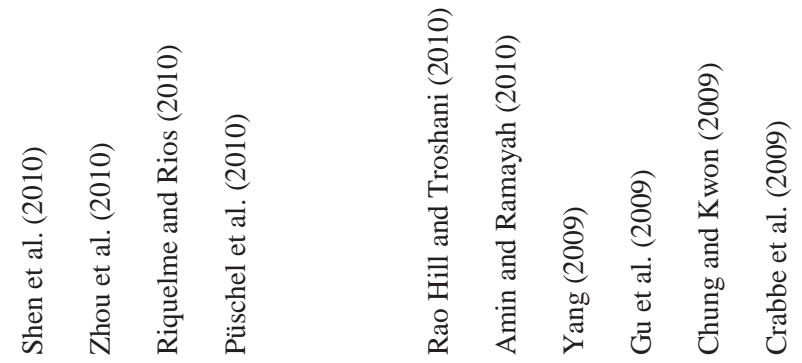

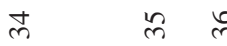

ले

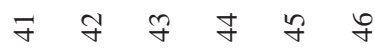




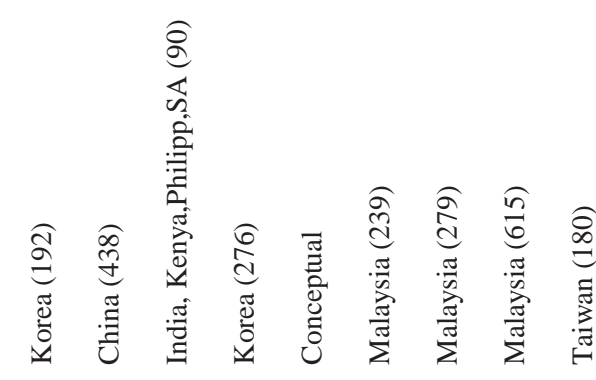

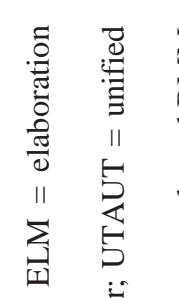

㻤泀

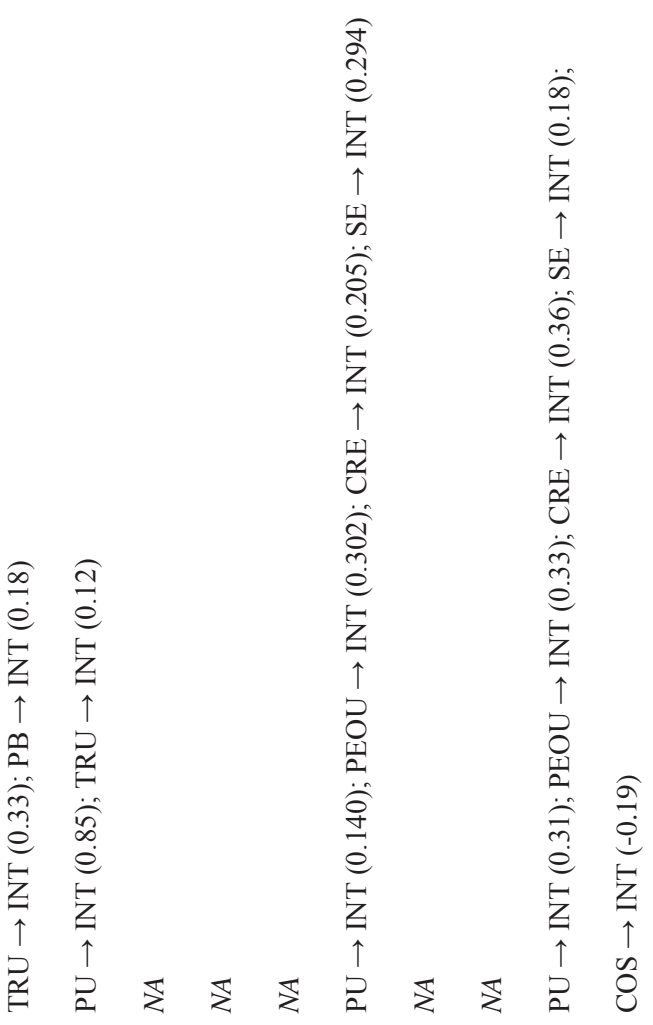

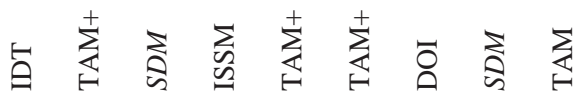

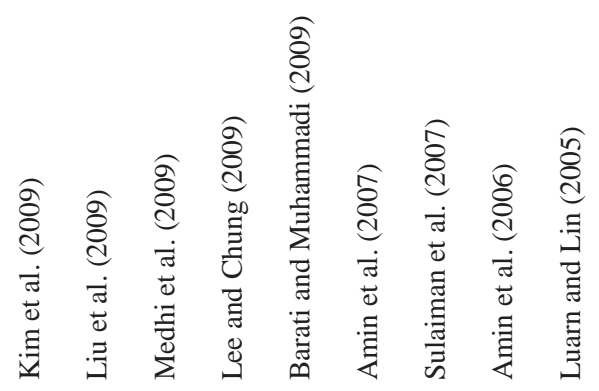

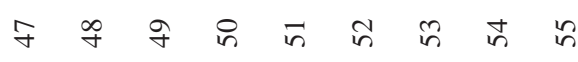


Table 5. Meta-analysis of average (means) path coefficients between antecedents of mbanking and attitude \& intention ${ }^{\mathrm{a}}$

\begin{tabular}{lcc} 
& Attitude & Intention \\
\hline Compatibility & 0.231 & 0.446 \\
Perceived usefulness & 0.342 & 0.380 \\
Attitude & - & 0.372 \\
Trust & $\mathrm{n} / \mathrm{a}^{\mathrm{a}}$ & 0.338 \\
Perceived ease of use & 0.246 & 0.278 \\
Credibility & $\mathrm{n} / \mathrm{a}^{\mathrm{a}}$ & 0.254 \\
Social influence & $\mathrm{n} / \mathrm{a}^{\mathrm{a}}$ & 0.244 \\
Perceived behavioral control/Self-efficacy & $\mathrm{n} / \mathrm{a}^{\mathrm{a}}$ & 0.229 \\
Perceived cost & $\mathrm{n} / \mathrm{a}^{\mathrm{a}}$ & 0.182 \\
Relative advantage & 0.381 & $\mathrm{n} / \mathrm{a}^{\mathrm{a}}$ \\
Risk & $\mathrm{n} / \mathrm{a}^{\mathrm{a}}$ & -0.148
\end{tabular}

${ }^{a}$ Average (mean) path coefficients were not calculated for the relationships if fewer than two studies used them. 
Appendix. Antecedents of m-banking adoption

\begin{tabular}{|c|c|c|c|c|}
\hline No. & ID & Description & Frequency & Theory \\
\hline 1 & PEOU & Perceived ease of use & 27 & TAM, IDT, SDM \\
\hline 2 & PU & Perceived usefulness & 23 & TAM, SST A/I UM \\
\hline 3 & TRU & Trust & 16 & BCF, IDT, ISSM, SDM, TAM, UTAUT \\
\hline 4 & SI & Social influence / Subjective norm & 15 & TAM, SDM, TPB, UTAUT \\
\hline 5 & RIS & Perceived risk & 14 & TAM, IDT, SDM, SST A/I UM, UTAUT \\
\hline 6 & SE & Self-efficacy & 11 & BCF, ELM, IDT, SDM, TAM, UTAUT \\
\hline 7 & COM & Compatibility (lifestyle, device) & 10 & IDT, SDM, TAM, UCF \\
\hline 8 & FC & Facilitation conditions & 9 & SDM, TAM, TTF, UCF, UTAUT \\
\hline 9 & COS & Cost & 8 & RMM, TAM, UTAUT, \\
\hline 10 & CRE & Credibility & 8 & IDT, TAM, UTAUT \\
\hline 11 & CUL & Culture & 8 & SDM, UTAUT \\
\hline 12 & DEM & Demographic factors & 8 & IDT, SDM, TAM, UTAUT \\
\hline 13 & SA & Structural assurance & 8 & ELM, SDM, TAM, UTAUT \\
\hline 14 & RA & Relative advantage & 6 & IDT, SDM, TAM \\
\hline 15 & ATT & Attitude toward use/m-banking & 5 & SDM, TAM, TPB \\
\hline 16 & SYSQ & System quality & 5 & ELM, ISSM, TAM, SDM \\
\hline 17 & TRI & Trialability & 5 & IDT, SDM, TAM, UTAUT \\
\hline 18 & $\mathrm{EE}$ & Effort expectancy & 4 & UTAUT \\
\hline 19 & IQ & Information quality & 4 & ELM, ISSM, SDM \\
\hline 20 & SEC & Security & 4 & BCF, SDM, TAM \\
\hline 21 & ACC & Accessibility & 3 & IDT, SDM, UTAUT \\
\hline 22 & CPX & Complexity & 3 & IDT, SDM \\
\hline 23 & CONV & Convenience & 3 & BCF, IDT, UTAUT \\
\hline 24 & NI & Need for interaction & 3 & SST A/I UM, TAM \\
\hline 25 & $\mathrm{~PB}$ & Perceived benefit & 3 & IDT, SDM, TAM \\
\hline 26 & PBC & Perceived behavioral control & 3 & BCF, SDM, TPB \\
\hline 27 & PERI & Personal innovativeness & 3 & IDT, SDM \\
\hline 28 & PERE & Performance expectancy & 3 & UTAUT \\
\hline
\end{tabular}




\begin{tabular}{|c|c|c|c|c|}
\hline 29 & SAT & Satisfaction & 3 & ISSM, UTAUT \\
\hline 30 & SPE & Speed & 3 & SDM, RMM, TAM \\
\hline 31 & UA & Uncertainty avoidance & 3 & SDM, UTAUT \\
\hline 32 & CA & Consumer awareness & 2 & TAM \\
\hline 33 & IMA & Image & 2 & SDM \\
\hline 34 & PRI & Privacy & 2 & IDT, SDM \\
\hline 35 & PEIN & Perceived innovativeness & 2 & SDM, TAM \\
\hline 36 & ENJ & Perceived enjoyment & 2 & SDM, TAM \\
\hline 37 & SQ & Service quality & 2 & ELM, ISSM \\
\hline 38 & UBI & Ubiquity & 2 & SDM \\
\hline 39 & AFF & Affordability & 1 & SDM \\
\hline 40 & ALE & Alertness & 1 & UTAUT \\
\hline 41 & BAN & Banking needs & 1 & IDT \\
\hline 42 & BEI & Behavioral introspection & 1 & $\mathrm{BCF}$ \\
\hline 43 & BEN & Benevolence & 1 & IDT \\
\hline 44 & COIN & Conventional interface & 1 & SDM \\
\hline 45 & DEV & Device type/features & 1 & SDM \\
\hline 46 & ECOF & Economic factor & 1 & SDM \\
\hline 47 & EXPEC & Expectations & 1 & SDM \\
\hline 48 & EXP & Experience & 1 & SDM \\
\hline 49 & EXPER & Expertise & 1 & BCF \\
\hline 50 & EXTI & External influence & 1 & SDM \\
\hline 51 & FREP & Firm reputation & 1 & IDT \\
\hline 52 & FLOW & Flow (experience) & 1 & SDM \\
\hline 53 & FU & Frequency of usage & 1 & SDM \\
\hline 54 & $\mathrm{FF}$ & Functional factor & 1 & SDM \\
\hline 55 & IP & Information presentation & 1 & ISSM \\
\hline 56 & INTEG & Integrity & 1 & IDT \\
\hline 57 & MPE & Mobile phone efficacy & 1 & UTAUT \\
\hline 5 & $\mathrm{OF}$ & Organizational factor & 1 & SDM \\
\hline
\end{tabular}




\begin{tabular}{|c|c|c|c|c|}
\hline 59 & PCOMP & Perceived competence & 1 & IDT \\
\hline 60 & PELIT & Perceived elitism & 1 & TAM \\
\hline 61 & PLBC & Perception of latest banking channels & 1 & SDM \\
\hline 62 & PINV & Personal involvement & 1 & ELM \\
\hline 63 & PERS & Personalization & 1 & UTAUT \\
\hline 64 & REPU & Reputation & 1 & SDM \\
\hline 65 & $\mathrm{RD}$ & Results demonstrability & 1 & SDM \\
\hline 66 & SITNO & Situational normality & 1 & TAM \\
\hline 67 & SC & Service compatibility & 1 & UTAUT \\
\hline 68 & SADO & Services adopted & 1 & SDM \\
\hline 69 & SF & Strategic factor & 1 & SDM \\
\hline 70 & TBI & Tag-based interface & 1 & SDM \\
\hline 71 & TCHA & Task characteristics & 1 & UTAUT \\
\hline 72 & $\mathrm{TF}$ & Technological factor & 1 & SDM \\
\hline 73 & TA & Technology anxiety & 1 & $\mathrm{BCF}$ \\
\hline 74 & TECHA & Technology characteristics & 1 & UTAUT \\
\hline 75 & TR & Technology readiness & 1 & ELM \\
\hline 76 & IM & Individual mobility & 1 & TAM \\
\hline 77 & UE & Utility expectancy & 1 & UTAUT \\
\hline 78 & VIS & Visibility & 1 & SDM \\
\hline 79 & IR & Innovation Resistance & 1 & TAM \\
\hline 80 & PD & Power Distance & 1 & UTAUT \\
\hline 81 & TTF & Task Technology Fit & 1 & TTF \\
\hline 82 & IND & Individualism & 1 & SDM \\
\hline 83 & LTO & Long-term orientation & 1 & SDM \\
\hline 84 & MAS & Masculinity & 1 & SDM \\
\hline
\end{tabular}

Notes: Frequency refers to the number of times a specific antecedent was used; the constructs are listed in descending order of their frequency. 